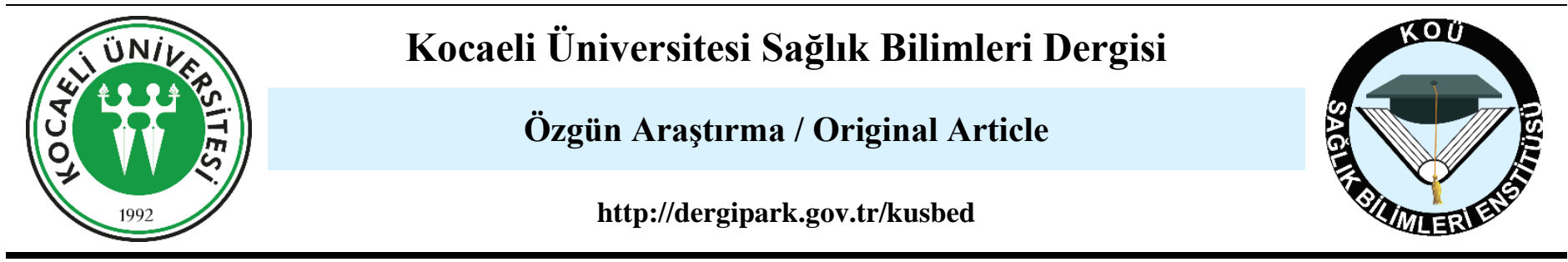

\title{
FIRST MOLECULAR DETECTION AND PHYLOGENETIC ANALYSIS OF ANAPLASMA PHAGOCYTOPHILUM IN HORSES IN MUŞ PROVINCE OF TURKEY
}

\author{
TÜRKIYY 'NIN MUŞ ILINDE ATLARDA ANAPLASMA PHAGOCYTOPHILUM'UN ILK MOLEKÜLER \\ TESPITI VE FILOGENETIKK ANALIZII
}

@(iD)Bekir Oğuz *1

${ }^{1}$ Van Yuzuncu Yil University, Faculty of Veterinary Medicine, Department of Parasitology, Van, Turkey

ORCID iD: Bekir Oğuz: 0000-0001-8720-3940

*Sorumlu Yazar / Corresponding Author: Bekir Oğuz e-posta / e-mail: bekiroguz @ yyu.edu.tr

Geliş Tarihi / Received: 11.03.2021

Kabul Tarihi / Accepted: 09.08.2021

Yayım Tarihi / Published: 31.10 .2021

\begin{abstract}
Objective: Equine granulocytic anaplasmosis (EGA) caused by Anaplasma phagocytophilum is a disease that generally develop characteristic high fever and a number of changes in blood such as thrombocytopenia. The main transmission of A. phagocytophilum is hard ticks through intrastadially. The aim of this study was to determine the presence of A. phagocytophilum in horses in Mus province of Turkey by using molecular methods.

Methods: In the present survey, blood samples were collected in Mus province from 93 horse. Commercial ELISA kit (IgG) and nested-PCR were performed. The DNA was extracted from blood and analysed by nested-PCR technique targeting 16S rRNA gene of A. phagocytophilum and then positive PCR products were sequenced.

Results: The seroprevalence against A. phagocytophilum was $8.6 \%$ and 6 horses (6.4\%) showed positive nested-PCR results. The sequences had 99.5 and $100 \%$ homology with the BLAST published A. phagocytophilum amplicons.

Conclusion: To the best of our knowledge, this is the first molecular data of A. phagocytophilum in horses in Mus province of Turkey. This study also reveals that A. phagocytophilum isolates isolated from a small region are closely related to A. phagocytophilum isolated from a wide variety of hosts.
\end{abstract}

Keywords: Anaplasma phagocytophilum, horses, phylogeny, Turkey, PCR, Mus

\section{$\ddot{\mathbf{O z}}$}

Amaç: Anaplasma phagocytophilum'un neden olduğu equine granülositik anaplasmosis (EGA), genellikle karakteristik yüksek ateş ve trombositopeni gibi kanda bir dizi değişiklik geliştiren bir hastalıktır. A. phagocytophilum' un biyolojik bulaşması intrastadial yolla sert keneler tarafından yapılmaktadır. Bu çalışmanın amacı, Türkiye'nin Muş ilinde atlarda A. phagocytophilum varlığının moleküler yöntemlerle belirlenmesidir.

Yöntem: Bu çalışma için Muş ilinde bakılan 93 attan kan örnekleri alındı. Ticari ELISA kiti (IgG) ve nested PCR yapıldı. DNA'lar kandan ekstrakte edildi ve A. phagocytophilum'un 16S rRNA genini hedef alan nested PCR tekniği ile analiz edildi. Daha sonra pozitif PCR ürünleri sekanslandi.

Bulgular: A. phagocytophilum'a karşı seroprevalans \% 8,6 bulunurken, 6 atın $(\%$ 6,4) nested PCR sonuçları pozitif bant gösterdi. Elde edilen sekanslar, BLAST tarafindan yayınlanan A. phagocytophilum amplikonlar ile \%99,5 ve \%100 benzerlik gösterdi.

Sonuç: Yaptığımız literatür taramalarına göre bu çalışma, Türkiye'nin Muş ilinde atlarda A. phagocytophilum'un ilk moleküler verisidir. Aynı zamanda, küçük bir bölgeden izole edilen A. phagocytophilum izolatlarının, çok çeşitli konakçılardan izole edilen A. phagocytophilum ile yakından ilişkili olduğunu ortaya koymaktadır.

Anahtar Kelimeler: Anaplasma phagocytophilum, atlar, filogeni, Türkiye, PZR, Muş 


\section{Introduction}

Tick-borne diseases (TBDs) are an increasingly outstanding health problem in all over the world, including Turkey. Some TBDs, particularly babesiosis, theileriosis and anaplasmosis are known to be prevalent in several geographic range of Turkey ${ }^{1}$ Among these, anaplasmosis is caused by six species (Anaplasma bovis, A. ovis, A. marginale, A. centrale, A. phagocytophilum and A. playts). ${ }^{2}$ Anaplasma phagocytophilum is found infected eukaryotic host cells such as neutrophils and eosinophilic granulocytes. Its is the main causative agent for equine granulocytic anaplasmosis (EGA). This pathogen also infects cats, dogs, wild carnivores, wild and domectic ruminants, rodents, and humans. The occurrence of A. phagocytophilum was found closely related to the distribution of the mainly vector Ixodes spp ticks ${ }^{3}$ In Turkey, Ixodes ricinus, Haemaphysalis sulcata, and Rhipicephalus bursa seems to be the only three vector $^{4}$

PCR technology based on genetic information have proved extremely useful for the diagnosis of EGA. ${ }^{3}$ In recent years, msp4, ankA, 16S rRNA, groESL, msp2 (P44) and gltA genes are used to detect $A$. phagocytophilum infections. ${ }^{5-8,29}$ On account of the fact that the 16S rRNA is a limited and preserved function gene has been more widely used in defining this agent. ${ }^{10}$ Recently, a $16 \mathrm{~S}$ rRNA nucleotide sequences investigation reported a new rickettsial genotype in horses in southern and eastern Europe. ${ }^{11}$ Moreover, this gene (EC9/EC12a and SSAP2f/SSAP2r primer set) is quite accurate for the diagnosis of $A$. phagocytophilum DNA in ruminants and ticks. ${ }^{12}$

Some studies conducted in Turkey have been reported DNA positivity for A. phagocytophilum in dogs, cattle, sheep and tick. Its has been also detected by serologic methods in mice and human ${ }^{1}$ On the other hand, a report is available on the detection of A. phagocytophilum in horses from Nevsehir province using IFAT, but the study lacks sequence analysis. ${ }^{13}$ Therefore, this study was aimed at the molecular identification and phylogenetic analysis of $A$. phagocytophilum in horses in Mus province of Turkey.

\section{Methods}

\section{Sample collection}

The study materials were blood samples collected from 93 healthy horses ranging in Mus province (39 29'28.29"N $41^{\circ} 06^{\prime} 41.47$ "E) of Turkey in June-August 2017 but was not found in any tick species. ${ }^{9}$ Whole blood samples were collected from the vena jugularis of the horses into EDTA tubes and serum tubes according to the technique, and the data on the animals were recorded with protocol numbers. The serum tubes were centrifugated at $3000 \mathrm{rpm}$ for $15 \mathrm{~min}$ and sera were separated. Both sera and blood EDTA tubes were stored at $-20^{\circ} \mathrm{C}$ until the time for serological and molecular analysis.

\section{ELISA (Enzyme-Linked ImmunoSorbent Assay)}

Samples were screened for IgG against A. phagocytophilum using commercially available ELISA assay from EUROIMMUN, Germany (Catalog no: EI 220m-9601 GE). This test detects antibodies from both active infection and previous exposures to the pathogen and has high sensitivity $(100 \%)$ and specificity $(90 \%)$.

\section{DNA extraction and Nested-PCR amplification}

Genomic DNA was obtained from the blood samples collected from the horses by using a commercial blood kit (EcoSpin Blood Genomic DNA Kit, Turkey). For the detection of A. phagocytophilum, primers targeting the $16 \mathrm{~S}$ rRNA gene were selected from the literature. Nested PCRs (nPCR) were performed using the EC9/ EC12a primers, which amplify a 1462 bp fragment, and SSAP2f/ SSAP2r, which amplify a $641 \mathrm{bp}$ fragment. ${ }^{14} \mathrm{PCR}$ was carried out in a final volume of $25 \mu \mathrm{L}$, containing $7.5 \mu \mathrm{L}$ DNase- and RNase-free sterile distilled water (Biobasic, Canada), $10 \mu \mathrm{L}$ $5 \mathrm{X}$ MyTaq Reaction buffer (Bioline, USA), $1 \mu \mathrm{L}$ of each primer (20 pmol), $5 \mu \mathrm{L}$ of template DNA (100-200 ng), and $0.5 \mu \mathrm{L}$ of Taq DNA polymerase recombinant $(5 \mathrm{U} / \mu \mathrm{L})$ (Thermo Scientific, USA).

A. phagocytophilum DNA from Genekam Biotecnology Company (Germany) validated by sequencing (Accession no. MW642479) was used as a positive control, and sterile water was used as the blank control for each run. The cycling conditions for the first and second round amplification involved $3 \mathrm{~min}$ of denaturation at $95{ }^{\circ} \mathrm{C}, 35$ cycles at $95{ }^{\circ} \mathrm{C}$ for $30 \mathrm{~s}$, annealing for $30 \mathrm{~s}$ at a temperature dependent on the primers applied $\left(50{ }^{\circ} \mathrm{C}\right.$ and $54^{\circ} \mathrm{C}$, respectively), and $72{ }^{\circ} \mathrm{C}$ for $1 \mathrm{~min}$, with a final extension step at $72{ }^{\circ} \mathrm{C}$ for $5 \mathrm{~min}$. PCR products were electrophoresed (Biorad, USA) in $1.5 \%$ agarose in Tris-acetate-EDTA (TAE) buffer and stained with ethidium bromide (SigmaAldrich, St-Louis MO, USA) to visualize the amplified DNA fragments with gel documentation system (Avegene, Taiwan).

\section{Sequence analysis}

The PCR products and primers coding the 16S rRNA gene region were properly packaged and sent to the Sentebiolab Company (Ankara) for performing DNA sequence analysis. The sequence chromatograms were checked and arranged using Bioedit software..$^{15}$ The final consensus sequences of our isolates were subjected to the "BLAST analysis" (http://www.ncbi.nlmn.nih.gov/BLAST) in the GenBank Database, and their similarity rates were compared with the isolates reported from different countries and hosts. Genetic distances were calculated using the Kimura 2 parameter model in MEGA 7.0. The 16S rRNA phylogenetic analysis data set was formed from the nucleotide sequences of 35 isolates in total. Babesia canis was used as the "out-group." The phylogenetic analyses and tree creation were carried out using the "maximum likelihood" method on MEGA 7.0 software with 1000 bootstrap replicates. ${ }^{16}$ The nucleotide sequences obtained in the study were recorded in the GenBank with the accession numbers of MW642476MW642478.

\section{Statistical analysis}

Statistical evaluation was carried out by the chi-squared and Fisher's exact test (SPSS 22 program) to analyze the results of seroprevalence and molecular in relationship to age, gender and breed of horses. $P$-values of less than 0.05 were considered significant.

\section{Results}

Eight $(8.6 \%)$ of the 93 sera examined were seropositive in terms of equine granulocytic anaplasmosis, using ELISA method. There were no statistically significant differences 
between age, gender and breed horses (for both molecular and serological results) (Table 1). The results of nested PCR of DNA showed $6.4 \%$ (6/93) of horses were positive to A. phagocytophilum (Figure 1). None of the 6 PCR positive horses were seropositive for A. phagocytophilum. We amplified three PCR products of the 16S rRNA for sequencing analysis. At the same time, our positive control was sequenced (MW642479). The three isolates (MW642476, MW642477 and MW642478) showed 100\% similar nucleotid with each other. The our isolates MW642476, MW642477 and MW642478 most closely related to the isolate detected in red deer from Poland (GQ450278) and in dog from South Africa (MK814406) (according to BLASTN analysis).

Phylogenetic analysis based on the 16S rRNA sequences showed that $A$. phagocytophilum comprised of two clades have emerged that are very sharply separated from each other (Figure 2). Clade 1 involved isolates from several hosts, including horses, sheeps, cats, human, dogs, goats, Brown rat,

cattle and ticks and this sequences identified with together the our three isolates and showed genetic affinity. Four sequences obtained in South Korea (cat, cattle and horse comprised for host, respectively) and Tunisia (horse) classified as clade 2 and were quite diverge from the isolates in our study. The current study sequences didn't form a separate clade. Hence, they showed similar homology among themselves. This configuration could be a sign of different adaptation of the patogen to the environment (geographic zones, ticks, hosts). If we compared our isolates and clade 2, there were distinct differences in numerous nucleotide sequences (Figure 3), pairwise distances were most 0.587 .

Table 1. Epidemiological data according to serological and molecular results

\begin{tabular}{|c|c|c|c|c|}
\hline & & $\begin{array}{c}\text { Study } \\
\text { population } \\
\mathrm{N}=93\end{array}$ & $\begin{array}{c}\text { ELISA } \\
\text { positive horses } \\
\mathrm{N}=\mathbf{8}(\%)^{*}\end{array}$ & $\begin{array}{c}\text { nPCR positive } \\
\text { horses } \\
\mathrm{N}=6(\%) \%\end{array}$ \\
\hline \multicolumn{5}{|c|}{ Age (years) } \\
\hline & $1-3$ & 11 & 0 & 0 \\
\hline & $4-9$ & 69 & $7(10.1)$ & $5(7.2)$ \\
\hline & $\geq 10$ & 13 & $1(7.7)$ & $1(7.6)$ \\
\hline \multicolumn{5}{|c|}{ Gender } \\
\hline & Female & 57 & $3(5.2)$ & $4(7)$ \\
\hline & Male & 36 & $5(13.9)$ & $2(5.5)$ \\
\hline \multicolumn{5}{|l|}{ Breed } \\
\hline & Mixed-breed & 50 & $3(6)$ & $5(10)$ \\
\hline & Arabian Horse & 39 & $4(10.3)$ & $1(2.5)$ \\
\hline & British Horse & 4 & $1(25)$ & 0 \\
\hline Total & & 93 & $8(8.6)$ & $6(6.4)$ \\
\hline
\end{tabular}

${ }^{*} p>0.05 ;$ statistically insignificant

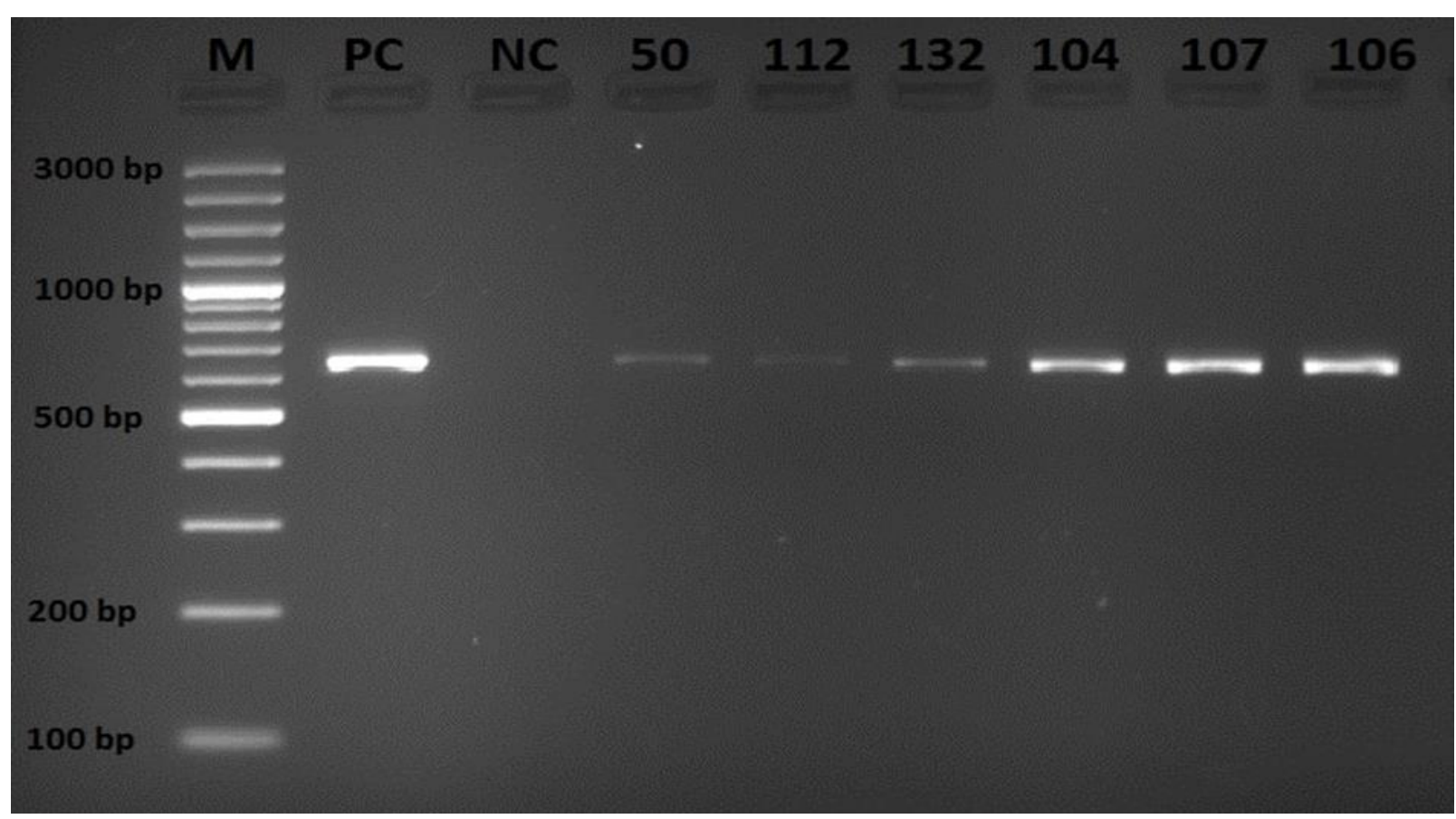

Figure 1. Anaplasma phagocytophilum positive samples on agarose gel at the 2nd step of the Nested PCR analyses. M: Marker (100bp), 50/112/132/104/107/106/: Positive samples, PC: Positive control, NC: Negative control 


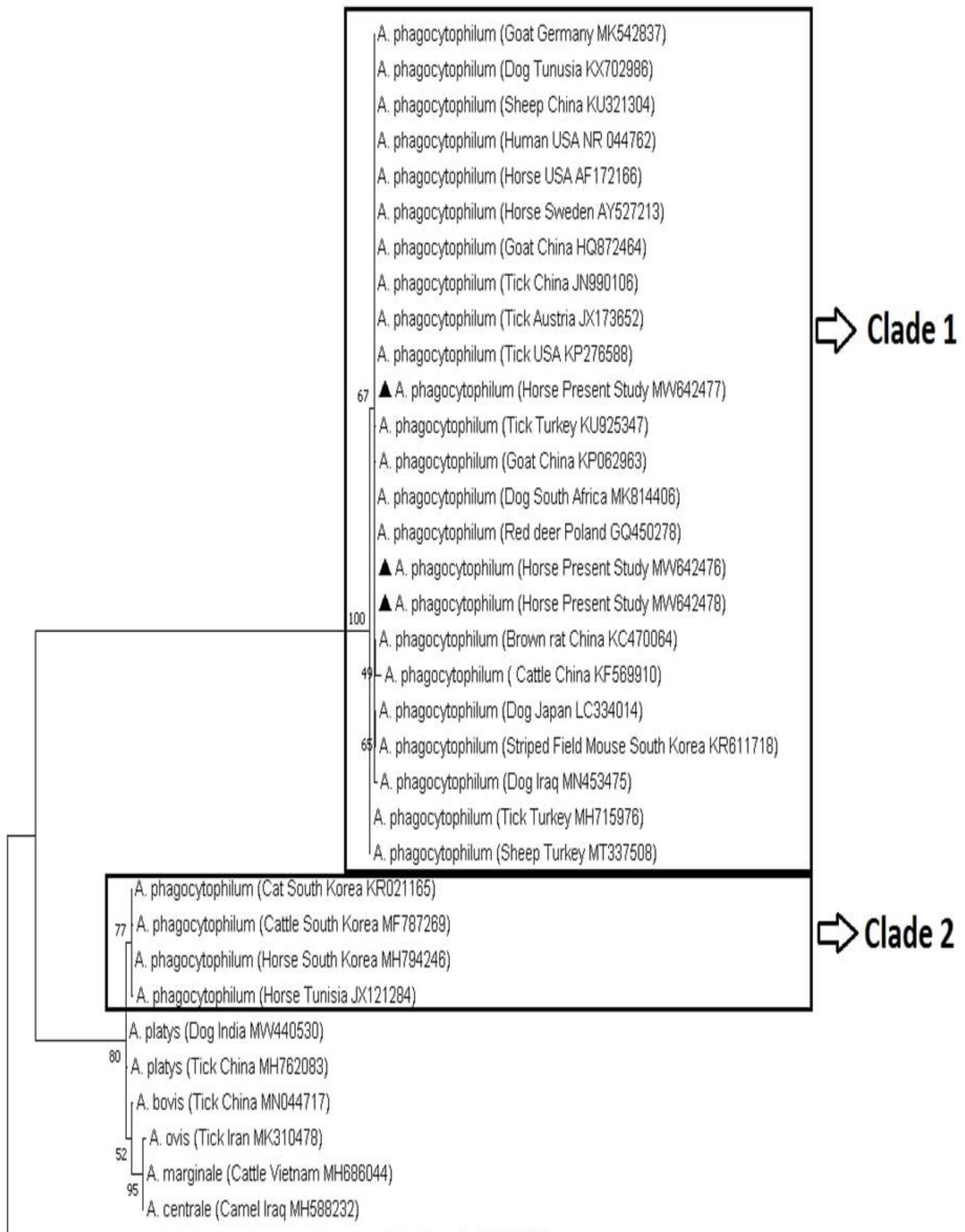

Babesia canis (MN625891)

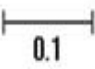

Figure 2. Maximum likelihood phylogenetic tree of A. phagocytophilum 16S rRNA gene sequences with 1,000 bootstrap replicates. Babesia canis isolate as outgroup (MN625891) used. Isolates from this study are indicated with a triangle round. Scale line shows the nucleotide change per site. 


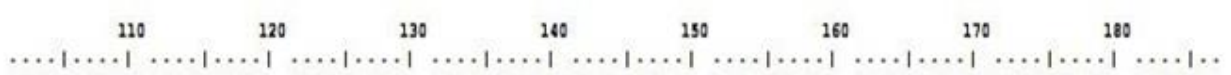

(Horse, Present Study, Mw642477 CTAACGCGTY AaGCACTCCG CCTGGGGACT ACGGTCGCAA GACTAAAACT CAAAGGAATT GACGGGGACC CGCACAAGCG GTGGAGC

(Horse, Present Study, MW642476

(Borse, Present Study, MW642478

(Horse, South Korea, MH794246)

(Cat, South Korea, KR021165)

(Horse, Tunisia , JX121284)

(Cattle, South Korea, MF787269

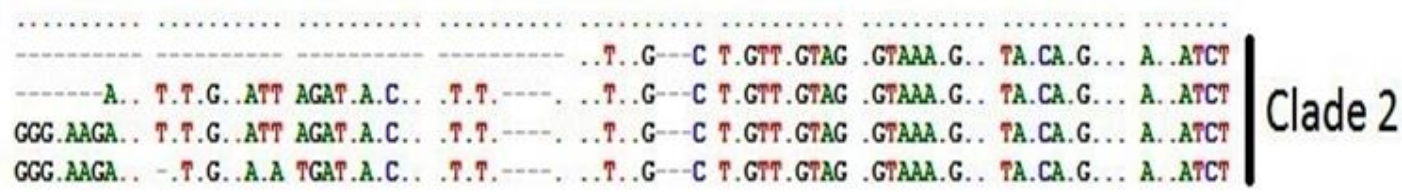

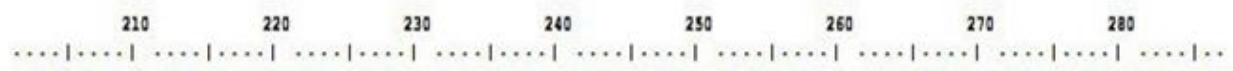

(Borse, Present Study, ww642477 CGATGCAACG CGAAAAACCT TACCACTCCT TGACATGGAG ATTAGATCCT TCTTAACGGA AGGGCGCAGT TCGGCTGGAT CTCGCAC

(Horse, Present Study, Lw642476

(Horse, Present Study, Mw642478

(Horse, South Korea, MH794246) (Cat, South Korea, KR021165)

(Horse, Tunisia , JX121284)

T. .GAGG.T. --.TC.G. .A C. .TGGAA. .

G. ACG. TCC...CT.C

GG.

(Cattle, South Korea, MF787269

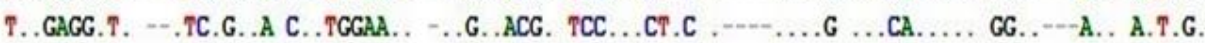

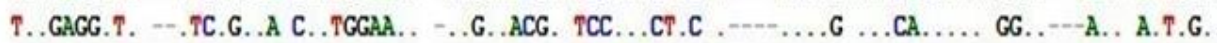

T..GAGG.T. --.TC.G. .A C..TGGAA.. -..G. ACG. TCC...CP.C .-...G ...CA.... GG..--A.. A.T.G..

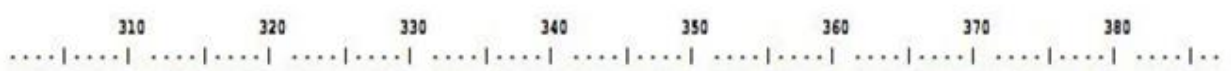

(Borse, Present Study, waw642477 CTGTCGTCAG CTCGTGTCG? GaGATGTTGG GTTAaGTCCC GCAACGAGCG TAACCCTCAT CCTTAGTTGC CAGCGGGTPA AGCCGGG

(Borse, Present Study, Mw642476

(Borse, Present Study, Mw642478

(Horse, South Korea, MH794246)

(Cat, South Korea, KR021165)

(Horse, Tunisia , JX121284)

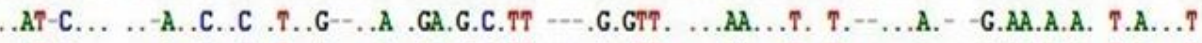

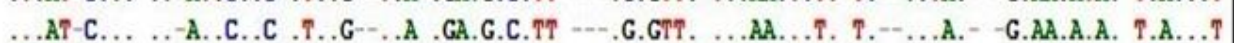

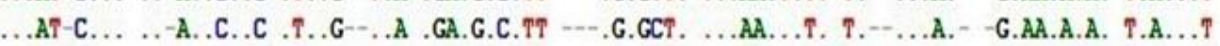

(Cattle, South Korea, MF787269

.AT-C... ..-A..C..C .T..G--.A. .GA.G.C.TT ---G.GPT.

AA...T. T.--...A.- -G.AA.A.A. T.A...T

Clade 2

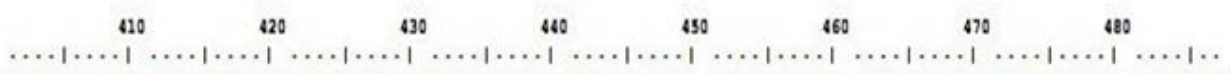

(Borse, Present Study, Mw642477 CTGCCAGTGG TAAACTGGag GAAGGTGGG ATGATGTCAa GTCAGCACG- GCCCTTATGG GGTGGGCTAC ACACGTGCTA CAATGGT

(Horse, Present Study, Mw642476

(Horse, Present Study, Mw642478

(Horse, South Korea, MH794246)

(Cat, South Korea, KR021165)

(Horse, Tunisia , JX121284)

G.C..G.CAA ACTC.GT.CC AGCA.CC.C. G.A..ACGG. .GGG...A.C .TTG. .CG.A AT.ATTGCG. GT.AAG.GC. TGTA..C G.C..G.CAA ACTC.GT.CC AGCA.CC.C. G.A. .ACGG. .GGG...A.C .TTG. .CG.A AT.ATTGGG. GP. AAG.GC. TGTA. .C (Cattle, South Korea, MF787269

G.C..G.CAA ACTC.GT.CC AGCA.CC.C. G.A. .ACGG. .GGG...A.C .TTG. .CG.A AT.ATTGGG. GP.AAG.GC. TGTA..C G.C..G.CAA ACTC.GT.CC AGCA.CC.C. G.A. .ACGG. .GGG...A.C .TTG. .CG.. AT.ATTGGG. GT.AAG.GC. TGTA..C

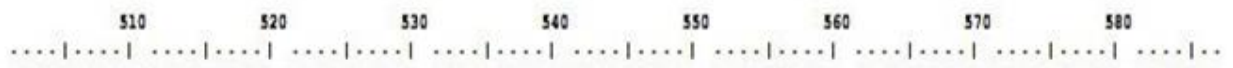

(Horse, Present Study, ww642477 TGCAATGTCG CAAGGCTGag CTAATCCGTA AAAGTCATCT CAGTTCGGaT TGTCCTCTGC AACTCGAGGG CATGAaGTCG GAATCGC

(Horse, Present Study, Mw642476

(Horse, Present Study, ww642478 (Horse, South Korea, 1H794246) (Cat, South Korea, KR021165) (Horse, Tunisia , JX121284) (Cattle, South Korea, MF787269

A-.G. .GA A.T.C.A.G. .T.A..C.G G.GC.GC.T. T.A.-. .C.AGACPA G.G..CG..A G.G..TAG.

A-..G..GA A.T.C.A.G. .T.A..C.G G.GC.GC.T. T.A.-.C .C.AGACPA G.G.CG..A G.G..TAG.. ...TC.

.A-.G..GA A.T.C.A.G. .T.A.C.G G.GC.GC.T. T.A.--C ..C.A

Figure 3. Multiple alignments of the primers designed from 16S rRNA gene region of our isolates A. phagocytophilum with the other A. phagocytophilum (especially Clade 2) sequences from GenBank.

\section{Discussion}

In this study, A. phagocytophilum was detected in horses for the first time in Mus province of Turkey by molecular methods. In addition, we detected a low prevalence of this patogen. The incidence of A. phagocytophilum may be associated with predominantly tick distribution or asymptomatic animals. The information on the epidemiology of the potential tick vectors is unclear in the Turkey. It has been detected in three species of ticks ( $I$. ricinus, $H$. sulcata, and $R$. bursa) so far. ${ }^{4}$ The present study, tick was not detected in any horse sample. Hence, the investigation of other tick species transmitting $A$. phagocytophilum in Turkey should be further executed.

A. phagocytophilum IgG antibodies have been detected in horses in Turkey (8.57\%). ${ }^{13}$ Our result was found to be approximately equal with the above report $(8.6 \%)$. There were no statistically significant differences between genders $(p>0.05)$. Similarly, M'ghirbi et al. ${ }^{17}$ and Laamari et al. ${ }^{18}$ reported that no significant differences in seroprevalence according to gender. On the contrary, there are previous studies reporting that higher seroprevalence in females than in males. ${ }^{19,20}$ Therefore, we assume that seroprevalence may be related to the housing and lifestyle of horses. British Horse proved to be the breed with the highest 
seroprevalence but we think that it does not provide an accurate epidemiological data for a total of four horses. The seroprevalence was significantly higher in 4-9 year-old horses in comparison to the other age groups. Though, the difference was not statistically significant $(p>0.05)$. Surprisingly, there is also a study in which young animals were infected at a higher rate. ${ }^{18}$ It is in accordance with other studies indicating that older animals were more frequently infected than young animals. ${ }^{20,21}$ These horses likely have been exposed to ticks contaminated with $A$. phagocytophilum for a longer period of time.

Investigating whether IgG antibodies have been formed for A. phagocitophylum offers an excellent screening method to detect the seroprevalence of pathogens. Immunologic studies with $A$. phagocitophylum demonstrated that first antibody titers against this pathogen occur after 19 days. In this case, the importance of molecular methods is revealed once again for earlier diagnosis. ${ }^{22,23}$ A. phagocytophilum DNA was detected by nested PCR in 6 blood samples among 93 tested horses $(6.4 \%)$. The molecular prevalence observed in the horse population in present study is substantially lower than the prevalence (19.6\%) lately observed among small ruminants living in the same geographical region. ${ }^{24}$ These small ruminants may have poteantially played a role in distribituon of the patogen such as vectors.

It has been reported that the GroEL and msp2 genes could separately describe A. phagocytophilum. ${ }^{25}$ Several studies have demonstrated that the pathogenicity or genotype of $A$. phagocytophilum would be determined especially by using the groEL gene region. ${ }^{8,} 26-28$ In the present study, we couldn't unable to replicate horses DNA using groEL fragment, in this way, we couldn't classify $A$. phagocytophilum with regard to genotype. The isolates belonging to clade 1 were most closely related to the isolate detected in dog from South Africa (MK814406). Researchers identified the isolate obtained from the dog in South Africa as a new variant "Aph1/GltA". ${ }^{29}$ These results demonstrate that $A$. phagocytophilum identified in horses in this study might be Aph1/GltA sequence variant. In this regard, there is a need to further study.

\section{Conclusion}

This is the first study to report molecular detection and phylogenetic analysis of A. phagocytophilum in horses in Mus province of Turkey. Our findings indicated that there was quite a change genetic mutability by comparison to the isolates of A. phagocytophilum circulating in the South Korea and Tunisa. Further studies are needed to research both the tick vectors and different host of this pathogen which has zoonotic potential.

\section{Conflict of Interest}

The author has no conflicts of interest.

\section{Compliance with Ethical Statement}

Ethics Committee approval for this research was obtained from the Local Ethics Committee for Animal Experiments of Van Yüzüncü Yıl University, (dated July 29, 2021, no. 2021/07-02).

\section{Financial Support}

This study was sponsored by Van Yuzuncu Yil University Scientific Research Project Fund and registered under Project No: THD-2020-9287.

\section{Author Contributions}

B.O: Design; B.O: Project development; B.O Literature search; B.O: Analysis; B.O: Manuscript writing; B.O: Critical review

\section{References}

1. Inci A, Yildirim A, Duzlu O, Doganay M, Aksoy S. TickBorne Diseases in Turkey: A Review Based on One Health Perspective. PLoS Negl Trop Dis. 2016; 10(12):e0005021. doi: 10.1371/journal.pntd.0005021.

2. Oğuz B, Özdal N, Kılınç ÖO, Karakuş A, Çelik BA, Değer MS. Van, Muş, Siirt ve Diyarbakır İllerinde Sığırlarda Anaplasmosis'in Seroprevalansi. Kocatepe Vet J. 2018;11(3):208-214. doi.org/10.30607/kvj.397726.

3. Pusterla N, Madigan JE. Equine Granulocytic Anaplasmosis. J Equine Vet Sci. 2013;33:493-496. doi.org/10.1016/j.jevs.2013.03.188.

4. Ceylan O, Byamukama B, Ceylan C, et al. Tick-Borne Hemoparasites of Sheep: A Molecular Research in Turkey. Pathogens. 2021;10(2):162. doi: 10.3390/pathogens10020162.

5. Fuente JDL, Massung RF, Wong SJ, et al. Sequence Analysis of the msp4 Gene of Anaplasma phagocytophilum Strains. $J$ Clin Microbiol. 2005;43(3):1309-1317. doi: 10.1128/JCM.43.3.1309-1317.2005.

6. Wang Y, Chen C, Zhang L. Molecular characterization of Msp2/P44 of Anaplasma phagocytophilum isolated from infected patients and Haemaphysalis longicornis in Laizhou Bay, Shandong Province, China. PLoS One. 2013;8:e78189. doi: 10.1371/journal.pone.0078189.

7. Smrdel KS, von Loewenich FD, Petrovec M, Županc TA. Diversity of ankA and msp4 genes of Anaplasma phagocytophilum in Slovenia. Ticks Tick Borne Dis. 2015;6(2):164-166. doi.org/10.1016/j.ttbdis.2014.11.008.

8. Chisu V, Zobba R, Lecis R, et al. GroEL typing and phylogeny of Anaplasma species in ticks from domestic and wild vertebrates. Ticks Tick Borne Dis. 2018; 9:31-36. doi: 10.1016/j.ttbdis.2017.10.012.

9. Akkoyun Z, Oğuz B. Seroprevalence of Theileria equi and Babesia caballi in horses of Mus province, Turkey. AJVS. 2019;60:22-29. doi: 10.5455/ajvs.22338.

10. Machado RZ, Teixeira MM, Rodrigues AC, et al. Molecular diagnosis and genetic diversity of tick-borne Anaplasmataceae agents infecting the African buffalo Syncerus caffer from Marromeu Reserve in Mozambique. Parasit Vectors. 2016;9:454. doi: 10.1186/s13071-016-1715-y.

11. Dzięgiel B, Adaszek L, Carbonero A, et al. Comparative analysis of 16S RNA nucleotide sequences of Anaplasma phagocytophilum detected in the blood of horses from various parts of Europe. J Med Microbiol. 2013;62:1891-1896. doi: 10.1099/jmm.0.058636-0.

12. Yang J, Liu Z, Niu Q, et al. Evaluation of different nested PCRs for detection of Anaplasma phagocytophilum in ruminants and ticks. BMC Vet Res. 2016;12(1):35. doi: 10.1186/s12917-016-0663-2.

13. Günaydın E, Pekkaya S, Kuzugüden F, Zeybek M, Gökmen TG, Ütük AE. The First Detection of anti-Anaplasma phagocytophilum Antibodies in Horses in Turkey. Kafkas Univ Vet Fak Derg. 2018;24(6):867-871. doi: 10.9775/kvfd.2018.20171.

14. Kawahara M, Rikihisa Y, Lin Q, et al. Novel genetic variants of Anaplasma phagocytophilum, Anaplasma bovis, Anaplasma centrale, and a novel Ehrlichia sp. in wild deer and ticks on two major islands in Japan. Appl Environ Microbiol. 2006; 72(2):1102-1109. doi: 10.1128/AEM.72.2.1102-1109.2006.

15. Hall T. Bio Edit: a user-friendly biological sequence alignment editor and analysis suite. Nucleic Acids Symp Ser. 1999;41:95-98. doi: 10.14601/Phytopathol_Mediterr14998u1.29.

16. Kumar S, Stecher G, Tamura K. MEGA7: Molecular Evolutionary Genetics Analysis Version 7.0 for Bigger 
Datasets. Mol Biol Evol. 2016;33(7):1870-1874. doi: 10.1093/molbev/msw054.

17. M'ghirbi Y, Yaïch H, Ghorbel A, Bouattour A. Anaplasma phagocytophilum in horses and ticks in Tunisia. Parasit Vectors. 2012;5:180. doi: 10.1186/1756-3305-5-180.

18. Laamari A, Azzag N, Tennah S, et al. Seroprevalence of Antibodies Against Anaplasma Phagocytophilum and Borrelia Burgdorferi in Horses (Equus Caballus) from Northern Algeria. J Vet Res. 2020;64(3):413-419. doi: 10.2478/jvetres2020-0045.

19. Praskova I, Bezdekova B, Zeman P, Jahn P. Seroprevalence of Anaplasma phagocytophilum in horses in the Czech Republic. Ticks Tick Borne Dis. 2011;2:111-115. doi.org/10.1016/j.ttbdis.2011.01.002.

20. Lee SH, Kim KT, Yun SH, et al. Serological and molecular detection of Anaplasma phagocytophilum in horse reared in Korea. Vet Med. 2015;60:533-538. doi: 10.17221/8491VETMED.

21. Laus F, Veronesi F, Passamonti F, et al. Prevalence of tick borne pathogens in horses from Italy. J Vet Med Sci. 2013;75:715-720. doi: 10.1292/jvms.12-0449.

22. Andel AEV, Magnarelli LA, Heimer R, Wilson ML. Development and duration of antibody response against Ehrlichia equi in horses. $J$ Am Vet Med Assoc. 1998;212:1910-1914. PMID: 9638192

23. Passamonti F, Veronesi F, Cappelli K, et al. Anaplasma phagocytophilum in horses and ticks: a preliminary survey of Central Italy. Comp Immunol Microbiol Infect Dis. 2010;33:73-83. doi: 10.1016/j.cimid.2008.08.002.

24. Altay K, Dumanl1 N, Aktas M, Özübek S. Survey of Anaplasma infections in small ruminants from East part of Turkey. Kafkas Univ Vet Fak Derg. 2014;20:1-4. doi: 10.9775/kvfd.2013.9189.

25. Seo MG, Ouh IO, Choi E, Kwon OD, Kwak D. Molecular Detection and Phylogenetic Analysis of Anaplasma phagocytophilum in Horses in Korea. Korean J Parasitol. 2018;56(6):559-565. doi: 10.3347/kjp.2018.56.6.559.

26. Haschke-Becher E, Bernauer R, Walleczek AM, et al. First detection of the Anaplasma phagocytophilum groEL-A genotype in man. $J$ Infect. 2010;60(4):300-305. doi: 10.1016/j.jinf.2009.12.010.

27. Rymaszewska A. Genotyping of Anaplasma phagocytophilum strains from Poland for selected genes. Folia Biol. 2014;62:37-48. doi: 10.3409/fb62_1.37.

28. Domenico MD, Pascucci I, Curini V, et al. Detection of Anaplasma phagocytophilum genotypes that are potentially virulent for human in wild ruminants and Ixodes ricinus in Central Italy. Ticks Tick Borne Dis. 2016;7:782-787. doi: 10.1016/j.ttbdis.2016.03.012.

29. Kolo AO, Collins NE, Brayton KA, et al. Anaplasma phagocytophilum and Other Anaplasma spp. in Various Hosts in the Mnisi Community, Mpumalanga Province, South $\begin{array}{lll}\text { Africa. } & \text { Microorganisms. }\end{array}$ doi.org/10.3390/microorganisms8111812. 